\title{
Strategic Feeding Alternating a 2-months' Feeding Restriction and a Short Boost of the Feeding Level Increases Conception Rate in Sheep
}

\author{
Narjess Lassoued ${ }^{1}$, Mourad Rekik ${ }^{2}$, Imene Ben Salem ${ }^{3}$, Samia Mleil ${ }^{1} \&$ Mariem Rouatbi $^{3}$ \\ ${ }^{1}$ Institut National de Recherche Agronomique de Tunisie, 43 Avenue Hédi Karray, 2049 Ariana, Tunisia \\ ${ }^{2}$ International Centre for Agricultural Research in the Dry Areas (ICARDA), P.O. Box, 950764 Amman 11195 , \\ Jordan \\ ${ }^{3}$ Ecole Nationale de Médecine Vétérinaire, 2020 Sidi Thabet, Tunisia \\ Correspondence: Mourad Rekik, International Centre for Agricultural Research in the Dry Areas (ICARDA), P.O. \\ Box, 950764 Amman 11195, Jordan. Tel: 962-065-903-120. E-mail: M.Rekik@cigar.org
}

$\begin{aligned} & \text { Received: November 5, } 2015 \\ & \text { Accepted: November 15, } 2015 \quad \text { Online Published: December 31, } 2015 \\ & \text { doi:10.5539/ijb.v8n1p80 }\end{aligned}$ URL: http://dx.doi.org/10.5539/ijb.v8n1p80

\begin{abstract}
This study aimed to investigate if feeding patterns prior to and after artificial insemination (AI) affect the reproductive performances of ewes. Two breeds were used; the Barbarine $(n=133)$ and Queue Fine de l'Ouest $(\mathrm{QFO} ; \mathrm{n}=129)$. For each breed, 2 experimental groups balanced for age and live weight were formed. For 75 days before AI, ewes in treatment High daily grazed for 6 hours and were supplemented with $0.6 \mathrm{~kg}$ of concentrate. For those in treatment Low-High, grazing was restricted to 3 hours only. From 21 days before insemination and the following 20 days, feeding pattern for Low-High ewes was switched to the High feeding regime. Changes in live weight and ovarian activity were monitored; conception rate and litter size were recorded. At the end of the restriction period and for both breeds, Low-High ewes reached lower live weights than High ewes $(p<0.05)$. Prior to AI and for both breeds, Low-High ewes weighed less than those in the High treatment group but no statistical differences were observed. At the end of the restriction period, more QFO ewes were cycling than for the Barbarine breed $(75 / 129$ vs. $55 / 133 ; p<0.01)$. Further, less QFO ewes in the Low-High treatment were cycling than High ewes (30/65 vs. 45/64; $p<0.01)$. More QFO ewes conceived to AI than Barbarine counterparts (77/112 vs. 73/130; $\mathrm{p}<0.05)$. For both breeds, higher proportions of ewes in the Low-High treatment groups conceived to AI but differences reached statistical significance only for Barbarine breed. Following a food-restriction period between weaning and mating, improved conception rates are achieved if the plane of nutrition is increased few weeks prior to and after $\mathrm{AI}$ in comparison to a continuous increase in live weight during the same period.
\end{abstract}

Keywords: reproduction, sheep, feed restriction, conception rate

\section{Introduction}

In many parts of North Africa, West Asia and even the southern shore of the European continent, sheep are mated in spring - early summer when photoperiod is unfavourable for reproduction and when a variable proportion of ewes in the flocks experience anoestrus. The "ram effect" whether followed by natural mating (Khaldi, 1984) or by artificial insemination (AI) (Rekik, Lassoued, Saadoun, Arous, \& Ben Sassi, 2003) was shown to be a powerful reproductive tool enabling local Tunisian breeds to be mated in such a way. In fact the "ram effect" is the response of anovulatory ewes, preconditioned by a period of isolation from rams to the introduction of rams by stimulating ovulation (Fulkerson, Adams, \& Gherardi, 1981). During March to June, when mating takes place for several Mediterranean breeds, broad seasonal and annual differences in rainfall and thermoperiod may result in large variations in feed supply and poor feeding on natural vegetation which contributes to impaired reproductive performances. In fact, based on the data of the World Meteorological Organization the month of March is characterized by lower temperature and greater rainfall (http://www.meteo.tn/htmlfr/donnees/juin.html). In the case of the fat-tailed Barbarine breed, which is a very frequent breed in Tunisia, altered nutrition of the ewes in spring that adds up to depleted body reserves after lactation reduces their response to the "ram effect" (Folch et al., 2000) and leads to severe losses in reproductive performance (Lassoued, Rekik, \& Ben Salem, 2009). These losses are partly explained by the incapacity of the ewes to respond to the ram effect and therefore resume ovulation (Lassoued et al., 2009). It is also reported (Branca, Mole, Sitzia, Decandia, \& Landau, 2000) that impaired fertilization of ova and a high rate of embryo losses are to be blamed. 
The stimulatory effect of nutrition on folliculogenesis and ovulation rate may be achieved by long- or short-term supplementations (Smith \& Stewart, 1990; Martin, Rodger, \& Blache, 2004; Scaramuzzi et al., 2006). Long-term inputs cause the "static effect", in which heavy females have higher ovulation rates than light animals. As to shortterm nutritional supplementation, we can differentiate the "dynamic effect" by an increase in body weight and condition by a higher feeding over 3-4 weeks before mating, and the "immediate or acute effect", in which a supplementation for 4-6 days around the time of preovulatory follicle selection ("focus-feeding") increases the ovulation rate in the absence of a detectable change in body weight. In practice, improvements of the nutritional level to boost reproduction are usually carried out for as short period as possible to be economic. However, and under extensive farming conditions, the induced-climatic changes of feed availability occur at longer terms (scale of months) and their incidence on the outcome of reproductive rhythms and performances has not been extensively addressed at the experimental level. The aim of this paper is therefore to investigate the effect of imposing two different feeding patterns: 75 days prior to artificial insemination and the subsequent 20 days on the reproductive performances of Barbarine and Queue Fine de l'Ouest (QFO) ewes that were synchronised with progestagens and the introduction of rams.

\section{Materials and Methods}

\subsection{Location, Animals and Design}

The experiment was conducted in the sylvo-agro-pastoral pilot farm of Saouaf (Office de l'Elevageet des Pâturages) under semi-arid conditions $\left(330 \mathrm{~mm}\right.$ average annual rainfall; $\left.35^{\circ} \mathrm{N}\right)$. The region experiences a Mediterranean climate with cool winters, hot dry summers and the possibility of recurrent droughts. On March the $15^{\text {th }}$ (early spring) a week after weaning, a total of 133 and 129 multiparous ewes of respectively the Barbarine and QFO were selected for the experiment. Barbarine ewes aged 3 to 8 years (mean live weight \pm SD. $38.7 \pm 4.24 \mathrm{~kg}$ at the start of the experiment) and QFO ewes aged 3 to 8 years (mean live weight \pm SD. $43.6 \pm 4.66 \mathrm{~kg}$ at the start of the experiment). Weaning took place when most of the lambs are 4 to 5 -months old. The lambs were separated from their dams after an adaptation period of one week during which the lambs had access to their mothers only during night time.

The experiment had a $2 \times 2$ factorial design; the 2 independent variables being the breed of sheep and the feeding pattern. Animals for each of the two breeds were assigned to 2 approximately equal sized groups balanced for age and live weight. From March the $15^{\text {th }}$ until May the $10^{\text {th }}$ (Restriction period; 55 days) and for both breeds, ewes in the first group (treatment Low-High) were allowed to graze natural pastures dominated by the native Medicago spp. (dry matter (DM) content of $899 \mathrm{~g} / \mathrm{kg}$ of fresh matter, $126 \mathrm{~g}$ crude protein (CP) per $\mathrm{kg}$ DM and $263 \mathrm{~g}$ of crude fibre per kg DM) for 3 hours per day. From May the $10^{\text {th }}$ until June the $20^{\text {th }}$ when the experiment ended, (Flushing period, 41 days), the ewes were allowed to graze for 6 hours/day and received $0.6 \mathrm{~kg} / \mathrm{ewe} /$ day of a soybean mealbarley based concentrate supplement containing $12.34 \mathrm{MJ}$ of metabolisable energy / $\mathrm{kg} \mathrm{DM}, 156 \mathrm{~g} \mathrm{CP}$ per kg DM and a DM content of $871 \mathrm{~g} / \mathrm{kg}$ of fresh matter. Treatment Low-High was designed to mimic a spring shortage of feed when animals maintain or lose body weight (Restriction period), followed by a substantial increase in the feeding level prior to and after mating (Flushing period). From March $15^{\text {th }}$ until the end of the experiment on June the $20^{\text {th }}$, ewes in treatment High and Low-High were allowed to graze pastures for 6 hours/day and daily supplemented with $0.6 \mathrm{~kg}$ /ewe concentrate. Treatment High was designed to mimic a steady, progressive body weight recovery between weaning and mating which is the management policy commonly adopted by the station to prepare animals for mating. Schedule of the time line of events during the experiment is reported in Figure 1.

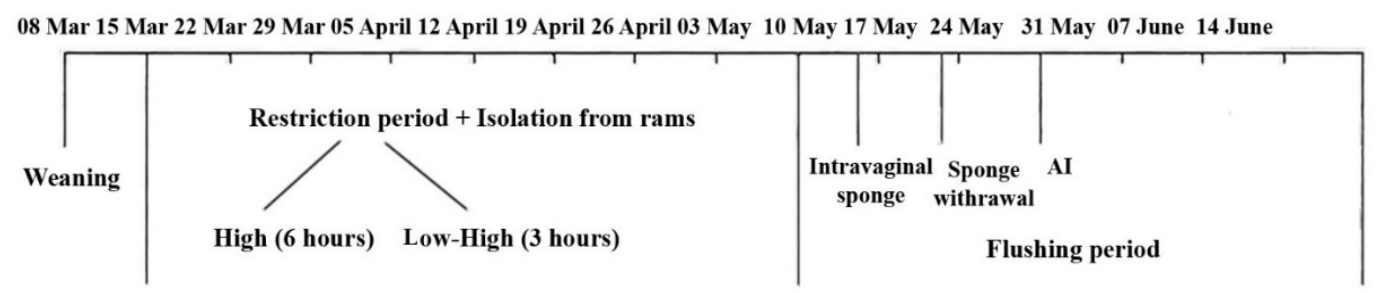

Figure 1. Schedule of the time line of events during the experiment; AI: Artificial insemination

\subsection{Management of Reproduction}

For both breeds and prior to artificial insemination, ewes in both treatment groups were strictly kept isolated from rams. In mid-May, intravaginal pessaries impregnated with $20 \mathrm{mg}$ cronolone (Chronogest ${ }^{\circledR}$; Intervet, Milton 
Keynes, UK) were inserted in all ewes and were left in-situ for 14 days. At sponge withdrawal, experimental ewes of both breeds were respectively joined to $10 \%$ of aproned adult Barbarine and QFO rams with proven libido and were continuously checked for oestrus by experienced technicians. When sponges are removed, ewes detected in oestrus within the first 36 hours or later were respectively inseminated with fresh semen at approximately 55 or 72 hours (Yves Cognié, Personal communication). Semen was collected by artificial vagina from 12 Barbarine and 8 Queue Fine de l'Ouest adult rams previously trained for semen collection using oestrous-induced ewes. Only ejaculates presenting a minimum concentration of $2.5 \times 10^{9} \mathrm{sperm}$ per $\mathrm{ml}$, measured by spectrophotometry at 540 $\mathrm{nm}$ (Accucell ${ }^{\circledR}$, Instruments de MédecineVétérinaire, IMV Paris, France) and a mass motility of at least 3.5 (determined on a scale of 5 using a contrast phase-microscope fitted with a heating plate) were selected for use. At each occasion, 2 consecutive ejaculates were collected from each ram at few minutes interval. Immediately after collection, the semen was diluted with a skimmed-milk diluent at $32-35{ }^{\circ} \mathrm{C}$ and ewes were inseminated cervically with $0.2 \mathrm{ml}$ of diluted semen containing in average $400 \times 10^{6}$ sperm. Within breed, semen from different ejaculates was at random attributed to ewes in both treatment groups. All inseminations were carried out by the same experienced technician and mean date of artificial insemination was May the $31^{\text {st }}$. The feeding regime was maintained for a further 20-day period after artificial insemination; during this period, the ewes were kept in isolation of rams and did not return to oestrus.

\subsection{Measurements}

Body weight for ewes of both breeds was measured 3 times using a weighing machine: at the beginning of the experiment, at the end of the restriction period and prior to artificial insemination that is 20 days in flushing period. Cycling ovarian activity for all the experimental ewes of both breeds was assessed by mid-ventral laparoscopy at the start of the experiment and at the end of the restriction period. In fact, animals were placed in dorsal recumbence in a metallic cradle with their heads tilted downwards at a $30-45^{\circ}$ angle. Moreover, laparoscopies were performed with a 5-mm endoscope (Karl Storz ${ }^{\circledR}$, Tuttlingen, Germany), under local anaesthesia, using $1 \mathrm{ml}$ of $2 \%$ procaine (Lidoject ${ }^{\circledR}$; Labesfal, Campo de Besteiros, Portugal) injected subcutaneously on the mid-ventral area, 3-4 cm anterior to the udder. The number of lambs born per ewe was recorded and this data allowed determining the number of ewes conceiving and then lambing due to artificial insemination as well as litter size.

\subsection{Statistical Analysis}

Results for live weight were analysed using the ANOVA procedure (SAS Version 9.1, SAS Inst. Inc., Cary, NC, USA, 2005). Sources of variation included breed, feeding regime, and breed $\mathrm{x}$ feedingregime interaction. The random variable was ewe within treatment. The effects of breed or feeding regime on binary variables such as animals ovulating or manifesting oestrus as well as on categorical variables such as ovulation rate and litter size were analysed using the CATMOD procedure (SAS Version 9.1, SAS Inst. Inc., Cary, NC, USA, 2005). Unless otherwise stated, all the values are presented as mean \pm standard deviation (SD).

\section{Results}

For live weight data, effects of the interaction breed $\mathrm{x}$ feeding regime were not significant at any weighing time $(p>0.05)$. At the end of the restriction period, Barbarine ewes of both treatment groups gained weight (Figure 2). However, the increase was much lower for the Low-High ewes and significant differences occurred in live weight between ewes in both treatment groups at the end of the restriction period $(\mathrm{p}<0.05)$. Over the same period, LowHigh ewes of the QFO breed slightly lost weight and ended up this first feeding period with a significantly $(\mathrm{p}<$ $0.001)$ lower live weight than High ewes ( $41.3 \pm 5.51$ vs. $47.1 \pm 4.89 \mathrm{~kg}$ for respectively Low-High and High ewes; Figure 2). When measured after 20 days in the flushing period, Low-High ewes of both breeds gained weight. Prior to AI and for both breeds, Low-High ewes weighed less than those in the High treatment group but no statistical differences were observed.

At the start of the experiment, $7 / 133(\approx 5 \%)$ and $21 / 129(\approx 16 \%)$ ewes of the Barbarine and QFO breeds were respectively shown to be cycling as assessed by the presence of at least one corpus luteum $(p<0.01)$. At the end of the restriction period and for both breeds, there was a substantial increase in the proportion of animals spontaneously cycling (Figure 3). Between breeds, more QFO ewes were cycling in comparison to those of the Barbarine breed (75/129 vs. 55/133; $p<0.01)$. Restriction period of feeding had no effect on the proportion of Barbarine ewes spontaneously cycling; figures being 26/66 and 29/67 for respectively ewes in treatments LowHigh and High (Figure 3). In contrast, the proportion of spontaneously cycling ewes for Low-High QFO ewes was significantly lower than for High ewes of the same breed at the end of the restriction period (30/65 vs. 45/64; $\mathrm{p}<$ $0.01)$. Neither breed, nor feeding regime affected ovulation rate being $1.08 \pm 0.18$ and $1.14 \pm 0.26$ for Barbarine ewes of respectively Low-High and High treatments. For the QFO breed, corresponding figures were $1.20 \pm 0.35$ and $1.19 \pm 0.30$ for Low-High and High ewes respectively. 
Panel A: Queue Fine de l'Ouest

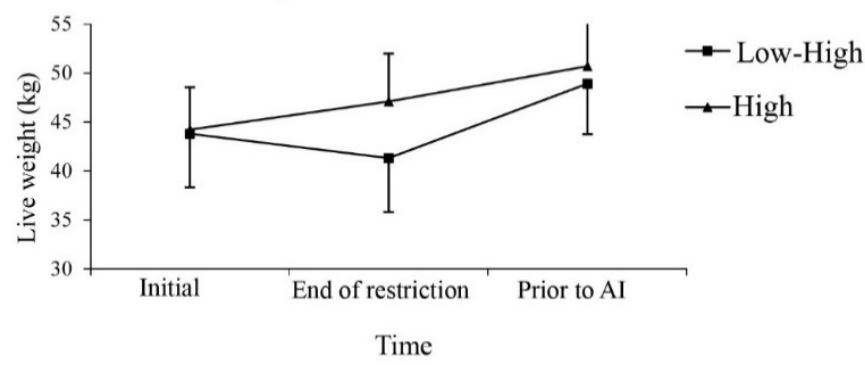

Panel B: Barbarine

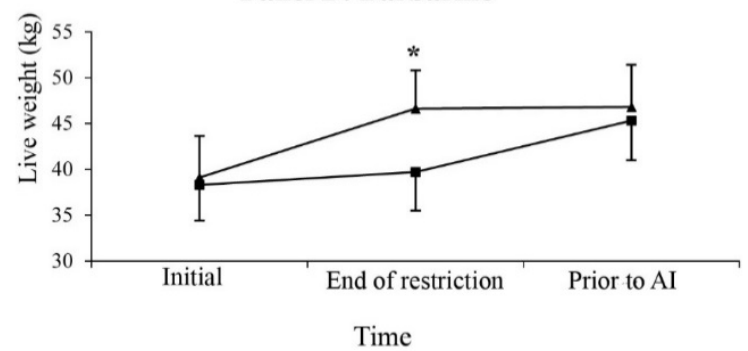

Figure 2. Live weight ( $\pm \mathrm{SD})$ variation during the experimental period (A: Barbarine; B: Queue Fine de l'Ouest); AI: Artificial insemination; * differences between Low-High and High treatments are significant $(p<0.05)$

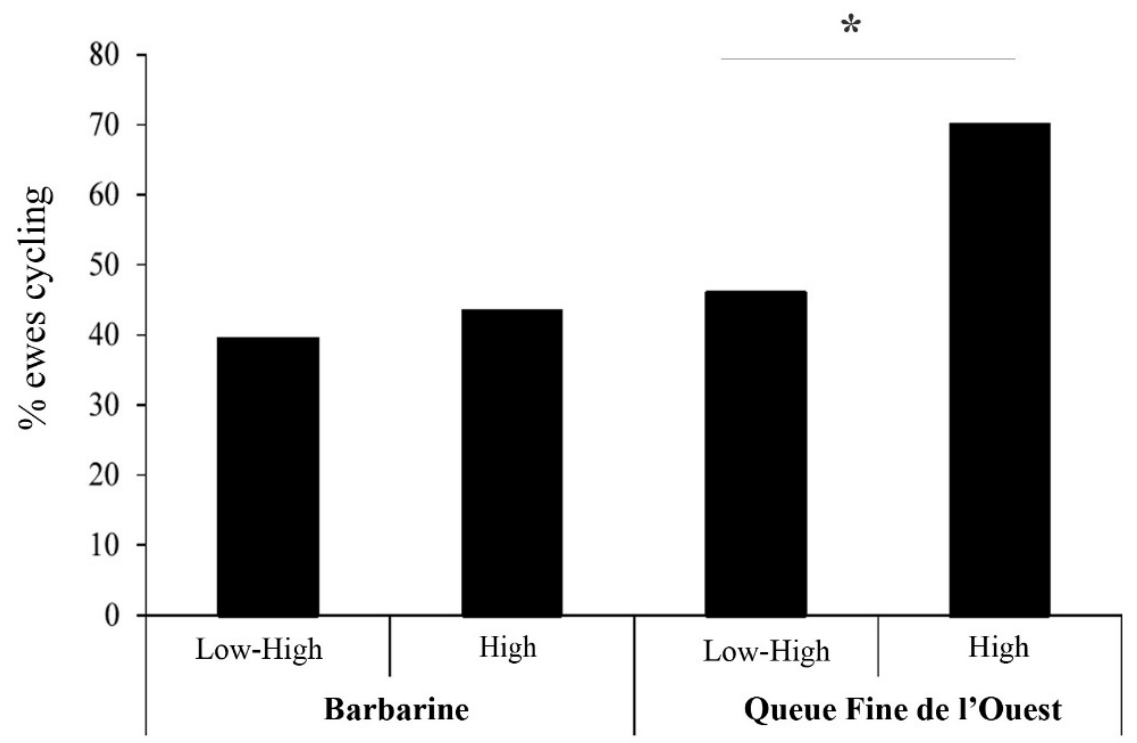

Figure 3. Proportions of ewes of the two breeds spontaneously cycling at the end of the restriction period; * differences between Low-High and High treatments are significant $(\mathrm{p}<0.05)$

Following withdrawal of the progestagen-impregnated sponges and introduction of rams, oestrous manifestation of the ewes of the Barbarine and QFO breeds were high (respectively 130/133, 97.7\% and 112/129, 86.8\%; p > 0.05 ) and unaffected by the feeding regime (Figure 4). For both breeds, most sheep (62 and 75\% for respectively Barbarine and QFO breeds) came into oestrus within the first 36 hours after removal of sponges and for both breeds these proportions were higher $(\mathrm{p}<0.05)$ than for those observed in oestrus after 36 hours. 


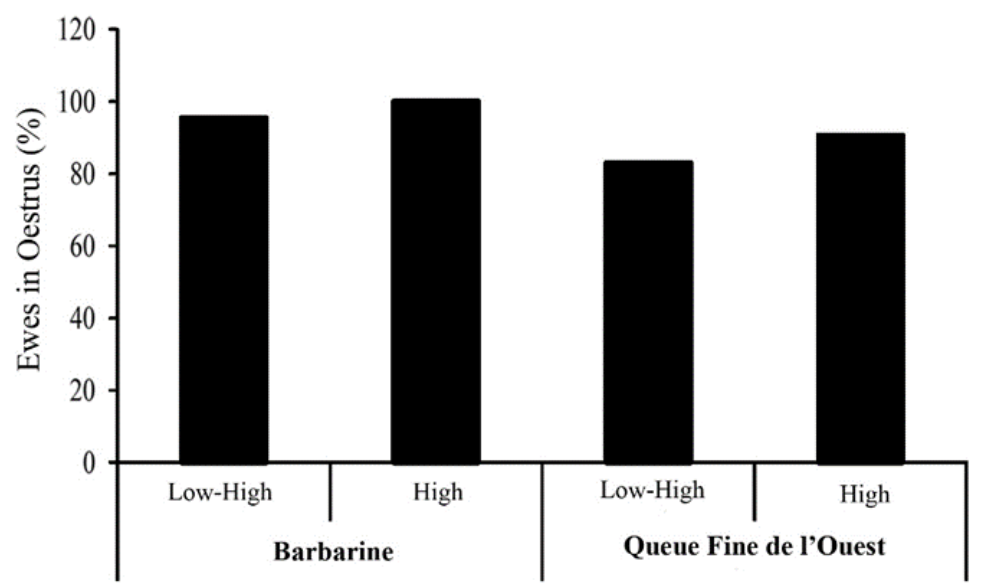

Figure 4. Proportions of ewes of the two breeds manifesting oestrus following progestagen priming and introduction of rams

The proportions of ewes conceiving to AI with relation to the ewes manifesting oestrus were very variable ranging between 46.3 and $75.9 \%$ (Table 1). Conception rate was higher for the QFO breed when compared to the Barbarine $(77 / 112 ; 68.7 \%$ versus $73 / 130 ; 56.1 \% ; p<0.05)$. For both breeds, higher proportions of ewes in the Low-High treatment groups conceived to AI when compared to their counterparts receiving the High feeding regimes (Table 1) but the difference reached levels of statistical significance only between Low-High and High treatments of the Barbarine breed. Litter size per ewe lambing is reported in table 1. No differences between treatments were observed between feeding regimes for the Barbarine breed. However, for the QFO breed, a higher $(\mathrm{p}<0.05)$ litter size was recorded for High ewes when compared to Low-High ewes.

Table 1. Ewes conceiving to artificial insemination (AI) and litter size at lambing

\begin{tabular}{lllll}
\hline Breed & $\begin{array}{l}\text { Treatment } \\
\text { group }\end{array}$ & $\begin{array}{l}\text { Ewes in } \\
\text { oestrus }\end{array}$ & $\begin{array}{l}\text { Ewes conceiving to AI (\%) } \\
\text { (proportion*) }\end{array}$ & $\begin{array}{l}\text { Litter size }( \pm \\
\text { SD) }\end{array}$ \\
\hline Barbarine & $\begin{array}{l}\text { Low-High (66) } \\
\text { High (67) }\end{array}$ & 63 & $42(66.6)^{\mathrm{b}}$ & $1.09 \pm 0.29^{\mathrm{a}}$ \\
& 67 & $31(46.3)^{\mathrm{a}}$ & $1.08 \pm 0.28^{\mathrm{a}}$ \\
& & & & \\
Queue Fine de & Low-High (65) & 54 & $41(75.9)^{\mathrm{a}}$ & $1.08 \pm 0.28^{\mathrm{a}}$ \\
l'Ouest & High (64) & 58 & $36(62.0)^{\mathrm{a}}$ & $1.22 \pm 0.42^{\mathrm{b}}$ \\
\hline
\end{tabular}

*Calculated in relation to the number of ewes manifesting oestrus after withdrawal of progestagen sponges and rams' introduction

${ }^{\mathrm{a}, \mathrm{b}}$ Within breed, means or proportions in the same column with different superscripts are significantly different $(\mathrm{p}<0.05)$.

\section{Discussion}

\subsection{Changes in Live Weight}

Initial difference in live weight between the Barbarine and QFO ewes are related to breed characteristics with QFO animals having a heavier weight than Barbarine counterparts (Rekik, Aloulou \& Ben Hamouda, 2005). In this trial, the imposed feeding regimes were successful in inducing differences in live weight culminating at significant deviations at the end of the restriction period between ewes in Low-High and High experimental groups. At the end of the restriction period, Low-High Barbarine ewes slightly gained weight, while under the same management and grazing conditions, Low-High QFO ewes lost weight, hence indicating a higher sensitivity of this latter breed to feed shortages. Differences in live weight between the two treatment groups faded after 20 days of flushing. This could be explained that Low-High ewes in both breeds have undergone compensatory growth following increase of their feeding level. For the Barbarine, rapid compensation is reported as one of the adaptive traits of 
this breed (Lassoued 1998; Ben Salem, Lassoued \& Rekik, 2011). For QFO ewes, High ewes maintained the highest live weight amongst all other experimental groups, perhaps explaining the higher litter size recorded for this group since within species, larger breeds tended to produce larger litters even if the reverse relationship can occurred and could be explained with the duration of pregnancy. In fact the gestation length of a species is positively related to adult body weight, the foetuses of larger species take longer to grow from conception to around $5 \%$ of their adult weight than those of smaller species (Michels, Decuypere \& Onagbesan, 2000)..

\subsection{Cyclic Ovarian Activity}

Initial proportions of cyclic ewes were low indicating the cumulated effects of increasing photoperiod (mid-March) and depletion of body reserves at the end of the suckling phase. Increases in the proportions of cyclic ewes between mid-March and early May are well documented for both breeds (Khaldi 1984; Lassoued \& Khaldi, 1995) and indicate the low depth of anoestrus under the prevailing photoperiod. The lower proportion of cycling Barbarine ewes initially and in May at the end of the restriction period may again underline differences between the two studied breeds in sensitivity to anoestrus. However, unlike temperate breeds, photoperiod is not the major factor affecting seasonality of reproduction. It acts in interaction with thermoperiod, nutrition and social stimuli (Gonzalez-Bulnes, Meza-Herrera, Rekik, Ben Salem \& Kridli, 2010). For breeds thriving in arid and semi-arid environments, nutrition is a key environmental factor influencing reproduction and with relation to the breeds included in this study, underfeeding Barbarine ewes during end of pregnancy and early lactation may deeply modify subsequent spring spontaneous ovulatory activity and decrease the percentage of cycling ewes in May (from 66\% to 34\%; Lassoued, 1998). In our case, this interaction was best expressed for QFO ewes as assessed by the significantly lower proportion of cycling Low-High ewes at the end of the restriction period.

\subsection{Oestrous Response}

The obtained oestrous response to introduction of rams after a period of progestagen priming is high for both breeds. A similar high response was reported by Rekik et al. (2003) for the Barbarine breed. Such response comprises a classic oestrous synchronisation of those ewes that were spontaneously cycling at the end of the restriction period. It also comprises a response to the ram effect for the ewes found not cycling. Indeed, these latter ewes were subjected to progestagen priming after examination of their ovaries in May and therefore, their oestrous response is likely the result of a "Ram Effect" induced ovulation (Rosa \& Bryant, 2002). For these ewes, progestagen priming allowed expression of oestrus at the induced ovulation; a similar result has been reported for the Barbarine breed by Lassoued and Khaldi (1990) with a synchronous oestrous expression between day 0 and day 4 after introduction of rams. For both breeds, absence of differences between experimental groups lends support to the conclusions of Atti, Bocquier and Khaldi (2004) that local Tunisian breeds thriving in harsh environments conserve a very high ability to reproduce despite broad changes in feeding provision and body condition.

\subsection{Conception Rate after Artificial Insemination}

Overall conception rate in this trial following progestagen priming and introduction of rams is nearly $62 \%$. Such rate is technically satisfactory and is even higher than the $49 \%$ conception rate reported for the same breed using a standard synchronising protocol that combines progestagen priming for 14 days and injection of 400 I.U. of eCG (Rekik \& Ben Sassi, 1996). It also compares to results emanating from large scale AI programmes in European countries (Meat and Livestock Commission 1982; Corteel \& Paquignon, 1984). The higher conception rate for QFO ewes is difficult to explain as for both breeds, care was taken to discard inappropriate ejaculates and insemination was carried out by the same trained technician according to the same procedures. Once again, this raises the question of possible differences between the two studied breeds with regards their reproductive potential and performances.

A valuable result that emerges from this study is the higher conception rate for Low-High ewes of both breeds when compared to High counterparts, though only significant for the Barbarine. For Low-High, elevation of the feeding level started 21 days before the mean date of insemination and therefore, this finding calls-up the classic "flushing effect" commonly reported in sheep flocks management and whereby, supply of extra feed prior to mating improves reproductive performance (Smith, 1991). Coincidentally, this finding is supported in early findings by Lamond and Bindon (1969) who provided evidence that in both the mouse and the ewe, a reduced plane of nutrition followed by refeeding on a high level, is associated with a greater ovulatory response.

It is concluded that for Barbarine and QFO ewes that populate the steppes of semi-arid and arid Tunisia, farmers can achieve satisfactory conception rates if the ewes maintain constant or slightly lose weight between weaning and mating and if the plane of nutrition is increased few weeks prior and after mating. Such strategy is apparently 
more profitable than adopting feeding strategies that would prompt a continuous increase in live weight between weaning and mating.

\section{Acknowledgements}

The contribution of Office de l'Elevage et des Pâturages to this work by allowing access to flocks of sheep is gratefully acknowledged.

\section{References}

Atti, N., Bocquier, F., \& Khaldi, G. (2004). Performance of the fat-tailed Barbarine sheep in its environment: adaptive capacity to alternation of underfeeding and re-feeding periods. A review. Animal Research, 53(3), 165-176. http://dx.doi.org/10.1051/animres:2004012

Ben Salem, H., Lassoued, N., \& Rekik, M. (2011). Merits of the fat-tailed Barbarine sheep raised in different production systems in Tunisia: digestive, productive and reproductive characteristics. Tropical Animal Health and Production, 43(7), 1357-1370. http://dx.doi.org/10.1007/s11250-011-9863-8

Branca, A., Mole, G., Sitzia, M., Decandia, M., \& Landau, S. (2000). Short-term dietary effects on reproductive wastage after induced ovulation and artificial insemination in primiparous lactating Sarda ewes. Animal Reproduction Science, 58(1-2), 59-71. http://dx.doi.org/10.1016/S0378-4320(99)00079-2

Corteel, J. M., \& Paquignon, M. (1984). Preservation of the male gamete (ram, buck, boar): Proceedings of the 10th international congress on animal reproduction and artificial insemination (pp. 20-27). Volume II. Illinois, USA: University of Illinois at Urbana-Champaign. Retrieved from http://agris.fao.org/agrissearch/search.do?recordID=US8623792

Folch, J., Lassoued, N., Khaldi, G., Hanocq, E., Bodin, L., Jurado, J. J., \& Chemineau, P. (2000). Plasticity of sheep and goat reproduction in the Mediterranean basin. Proceedings of the joint ANPA-EAAP-CIHEAMFAO symposium on livestock production and climatic uncertainty in the Medietrannean (pp. 237-245). Agadir, Morocco: EAAP publication.

Fulkerson, W. J., Adams, N. R., \& Gherardi, P. B. (1981). The ability of wethers treated with oestrogens or testosterone to induce and detect oestrus in ewes. Applied Animal Ethology, 7(1), 57-66. http://dx.doi.org/10. 1016/0304-3762(81)90051-1

Gonzalez-Bulnes, A., Meza-Herrera, C. A., Rekik, M., Ben Salem, H., \& Kridli, R. T. (2010). Limiting Factors and Strategies for Improving Reproductive Outputs of Small Ruminants Reared in Semi-Arid Environments. In: Degenovine. K.M (ed.), Semi-Arid Environments: Agriculture, Water Supply and Vegetation (pp. 41-62). Hauppauge, New York Nova: Science Publishers.

Institut National de la météorologie. (n.d.). Donnees Climatiques Mensuelles. Retrieved from http://www.meteo. tn/htmlfr/donnees/juin.html

Khaldi, G. (1984). Variations saisonnières de l'activité ovarienne, du comportement d'oestrus et de la durée de l'anoestrus post-partum des femelles ovines de race Barbarine: influence du niveau alimentaire et de la présence du mâle (Seasonal variations of ovarianactivity, oestrousbehaviour and the duration of postpartum anoestrous of Barbarineewes: influence of the level of feeding and the presence of males) (Unpublished doctoral dissertaion). Université des Sciences et Techniques du Languedoc, Académie de Montpellier, France.

Lamond, D. R., \& Bindon, B. M. (1969). Effect of nutrient intake on ovulation in mice and sheep. Biology of Reproduction, 1(3), 264-271. http://dx.doi.org/10.1095/biolreprod1.3.264

Lassoued, N. (1998). Induction de l'ovulation par "effet bélier" chez les brebis de race Barbarine en anoestrus saisonnier: mécanismes impliqués dans l'existence du cycle ovulatoire de courte durée (Induction of ovulation using the "ram effect » in Barbarine ewes during seasonal anoestrus: mechanisms involved in the existence of ovulatory cycles of short duration). (Unpublished doctoral dissertaion). Faculté des Sciences de Tunis, Université de Tunis II, Tunisie.

Lassoued, N., \& Khaldi, G. (1990). Influence d'un traitement progestatif associé à des doses croissantes de PMSG sur les performances de reproduction des brebis de race Barbarine. Annales de l'Institut National de la Recherche Agronomique de Tunisie, 63(4), 1-12.

Lassoued, N., \& Khaldi, G. (1995). Variations saisonnières de l'activité sexuelle des brebis de races Queue Fine de l'Ouest et Noire de Thibar. In G. Caja, M. Djemali, D. Gabina, \& A. Nefzaoui (Eds.), L'élevage ovin en zones arides et semi-arides. Cahiers Options Méditerranéennes, 6, 27-34. Retrieved from http://om.ciheam. org/om/pdf/c06/95605382.pdf 
Lassoued, N., Rekik, M., \& Ben Salem, H. (2009). Influence of supplementary feeding and the ram effect on conception rate of Barbarine ewes during spring mating. In T. G. Papachristou, Z. M. Parissi, H. Ben Salem, P. Morand-Fehr (Eds.), Nutritional and foraging ecology of sheep and goats. Options Méditerranéennes (pp. 405-409). http://om.ciheam.org/om/pdf/a85/00801035.pdf

Martin, G. B., Rodger, J., \& Blache, D. (2004). Nutritional and environmental effects on reproduction in small ruminants. Reproduction, Fertility and development, 16(4), 491-501. http://dx.doi.org/10.1071/RD04035

Meat and Livestock Commission (MLC). (1982). Sheep artificial insemination. Veterinary Services Technical Bulletin, Milton Keynes, UK.

Michels, H., Decuypere, E., \& Onagbesan, O. (2000). Litter size, ovulation rate and prenatal survival in relation to ewe body weight: genetics review. Small Ruminant Research, 38(3), 199-209. http://dx.doi.org/10.1016/ S0921-4488 (00)00169-3

Rekik, M., \& Ben Sassi, M. (1996). Lambing outcome in native fat-tailed sheep flocks following AI: effect of timing of insemination. In J. A. M. Van Arendonk (Ed.), Proceedings of the 47th annual meeting of the European Association of Animal Production (pp. 240). Lillehammer, Norway.

Rekik, M., Aloulou, R., \& Ben Hamouda, M. (2005). Small ruminant breeds of Tunisia. In L. Iniguez (Ed.), Characterisation of Small Ruminant Breeds in West Asia and North Africa North Africa, International Centre for Agricultural Research in the Dry Areas (ICARDA) (pp. 91-140). Aleppo, Syria.

Rekik, M., Lassoued, N., Saadoun, L., Arous, M., \& Ben Sassi, M. (2003). Using the ram effect as an alternative to ECG before artificial insemination of Barbarine ewes. Journal of Animal and Veterinary Advances, 2, 225230. http://medwelljournals.com/abstract/?doi=javaa.2003.225.230

Rosa, H. J. D., \& Bryant, M. J. (2002). The 'ram effect' as a way of modifying the reproductive activity in the ewe. Small Ruminant Research, 45(1), 1-16. http://dx.doi.org/10.1016/S0921-4488 (02)00107-4

Scaramuzzi, R., Campbell, B., Downing, J., Kendall, N., Khalid, M., Munoz-Gutierrez, M., \& Somchit, A. (2006). A review of the effects of supplementary nutrition in the ewe on the concentrations of reproductive and metabolic hormones and the mechanisms that regulate folliculogenesis and ovulation rate. Reproduction Nutrition Development, 46(4), 339-354. http://dx.doi.org/10.1051/rnd:2006016

Smith, J. F. (1991). A review of recent developments on the effect of nutrition on ovulation rate (the flushing effect) with particular reference to research at Ruakura. Proceedings of the New Zealand Society of Animal Production, 51, 15-23. http://agris.fao.org/agris-search/search.do?recordID=NZ9127363

Smith, J. F., \& Stewart, R. D. (1990). Effects of nutrition on the ovulation rate of ewes. In C. M. Oldham, G. B. Martin, \& I. W. Purvis (Eds.), Reproductive Physiology of Merino Sheep. Concepts and Consequences. School of Agriculture (Animal Science). The University of Western Australia (pp. 85-101). Perth, Australia.

Statistical Analysis Systems (SAS) Institute Inc. (2005). User's Guide (version 9.1). SAS Institute, Inc., Cary, NC, USA.

\section{Copyrights}

Copyright for this article is retained by the author(s), with first publication rights granted to the journal.

This is an open-access article distributed under the terms and conditions of the Creative Commons Attribution license (http://creativecommons.org/licenses/by/3.0/). 